\title{
Social Media Use in the Public Sector: The Evolving Legal Landscape \& Unique Challenges
}

\author{
Dr. Shamima Ahmed, Professor \\ Dept. of Political Science, Criminal Justice, and OL \\ Northern Kentucky University \\ Nunn Drive, FH 555k \\ Highland Heights, KY 41099, United States
}

Received: Dec. 16, 2019 Accepted: Jan. 17, 2020 Online published: Feb. 3, 2020

doi:10.5296/jpag.v10i1.16382ＵRL: https://doi.org/10.5296/jpag.v10i1.16382

\section{Introduction}

Social media, originally started as a personal and social networking tool, is now an essential resource in the workplace. The use of Facebook, Twitter, Blogs, Flickr, LinkedIn, YouTube and other social media applications in the workplace are not only widespread but are increasingly viewed as an essential resource. Employers use social media for recruitment, public relations, fundraising, disseminating information, instantaneous communication with stakeholders, and for many other purposes. Employees, on the other hand, use it for networking, job related activities, communication with colleagues about workplace issues, and often times for non-work related matters. The practical benefits of use of social media in the workplace cannot be overemphasized.

Increasingly more and more government organizations are also using social media. In addition to its commonly understood benefits (such as, efficiency, networking, online meetings, instant communication), social media has a much more important and useful role in government organizations. Mergel (2013) explained three such purposes/usefulness for social media use in government organizations: (1) increase transparency, (2) support inter and intraorganizational collaboration, and (3) enable innovative forms of public participation and engagement (p.3). Tappendorf et al (2013) mentioned several other benefits, such as timely and cost-effective communication, creating real-time public record of project information, increasing public participation and encouraging social activism, garnering support for government projects, publicizing public meetings, providing public safety information, networking and marketing. Social media use in government organizations is different from E-Government applications; the latter are designed to inform, educate, and allow individuals to submit forms (such as IRS income tax filing) and provide an online platform for citizens' 
feedback.

The increasing use of social media in the workplace, however, is posing several challenges for both the employers and employees of public sector organizations, and some of these challenges involve legal issues. These legal issues range from whether employers could make hiring or firing decisions based on employees' social media postings to employees' privacy rights and to freedom of information issues. Unfortunately, the legal landscape of workplace social media use, at the present time, is only at a developing stage and at times has been confusing. No matter how confusing this legal landscape may appear to be, recent developments do provide valuable guidance to managers and leaders who are increasingly faced with a variety of legal issues related to the use of social media. However, one wonders whether public sector employees, in general, are aware of these recent legal developments.

This paper discusses some of these legal issues that apply to government organizations, and the evolving landscape of that. It also includes a short case study that reports the findings from a brief quiz completed by students in a Master's in Public Administration (MPA) Program at a Midwestern University. One of the purposes of this brief quiz was to assess the level of knowledge that these students, who were pre-dominantly in-career students, had on some of these legal issues and developments. Students in this MPA program were residents of a metropolitan region composed of three adjacent states.

The discussion is organized around the following sections:

1. Unique legal issues that government organizations face with the use of social media.

2. Relevant laws and policy guidance enacted by Congress, State Legislature and by various federal agencies.

3. Findings from the brief quiz that students completed.

\section{Legal Issues Related to Social Media Usage in Government Organizations}

Government organizations use social media in various ways. At the local level, Amber Alerts, other emergency alerts, severe weather alerts, construction updates, road closings and many similar announcements/alerts are now widely used by many organizations. It is also now quite common to see various state and federal agencies using Facebook, Twitter, LinkedIn, YouTube and other social media in their efforts to not only communicate effectively with stakeholders but also to maintain transparency and accountability. At the national level, the use of social media was exemplified during the past national elections. During the 2008 Presidential campaign, Barak Obama and his campaign team used social media extensively to reach constituents and potential voters and accomplished that with great success (Carpenter, 2009). During the most recent national election, both Hillary Clinton and Donald Trump used social media extensively during their campaigns. Russel (2017) points out, ". . . the course of 2016 election was undeniably influenced by social media". There are several issues, with legal implications, that employers and employees may ponder when it comes to the use of social media. Could an employer make employment related decisions based on a prospective employee's or a current employee's social media posts? Could an employer ask employees to share the passwords of their private social media accounts? Could employees share their 
concerns regarding management with each other in social media? What about employers holding meeting online - are those subject to the open meeting laws that apply to government organizations? Public sector employers and employees are increasingly facing these issues with the unprecedented use of social media.

The following section explains some of these legal issues as they pertain to government organizations:

\subsection{Freedom of Speech (First Amendment)}

Since public sector employees enjoy the first amendment's freedom of speech right in the workplace, employees' social media use poses several challenge and issues in government organizations. Courts usually apply these three prong tests to deliberate and decide on government employees' freedom of speech cases: (1) the speech must be on a matter of public concern, (2) the speech must fall outside of the employees' job duties, and (3) the employee's interests in free speech must outweigh the government's interest in efficient and effective provisions of services. These tests are developed based on the Pickering v. Board of Education (1968) and Garcetti v. Ceballos (2006) rulings.

A 2013 case (Bland v Roberts) ruling sheds some lights on the issue of employees versus employers' rights when it comes to the First Amendment and workplace social media use. The case involved a group of employees of the Sheriff department who filed a First Amendment case against the Sheriff. They alleged that they were fired from their jobs due to their political affiliations and for supporting the Sheriff's opponent for re-election, who had lost the election. Two of the plaintiffs had clicked "like' on the candidate's Facebook page, and one of them had posted a comment on the opponent's Facebook page. The district court judge ruled in favor of the Sheriff, explaining that the plaintiffs' speech activities were not the cause of their dismissals, and that Facebook "likes" were not speech at all and hence did not fall under the First Amendment rights. The Fourth Circuit Court reversed the decision and concluded that liking someone's Facebook page was speech and therefore falls under the plaintiffs' First Amendment rights.

Courts seem more likely to protect employees' social media use if they are using it from home rather than in the workplace. If an employee is posting on social media while at work about matters of public concern, courts may find such speech more disruptive and probably unprotected compared to someone doing the same from home and during non-work hours (Nolo, 2011). Employees' postings an agency's confidential information is clearly not a protected speech.

Another unique issue for government organizations is whether a government organization's social media site is considered a "public forum". Tappendorf (2013) explains the three types of public forums: traditional, designated, and nonpublic. "A traditional public forum includes places that are traditionally used for assembly, debate, and other 'expressive' activities, including streets, sidewalks, and parks. .. If a government tries to place restrictions on the content of speech in a traditional public forum, these restrictions must be necessary to serve a compelling government interest" (p. 5). A nonpublic forum is a place that is not by tradition or designation a forum for the public to communicate with each other. An agency website is 
an example of a nonpublic forum. Tappendorf (2013) explains that a designated public forum is one where a government agency has intentionally opened a nonpublic forum for public discourse. A 'limited public forum' is a subcategory of a designated public forum, where the government agency has intentionally opened it up to certain groups or certain topics. Here the agency can restrict and reserve access to certain topics and groups if the restrictions are not because of the opinion or ideology of the speaker or the group. City council meetings are examples of this type of forum. If the government agency allows others to post materials of their choosing on a website, blog, or social network site, then one can make a legal case that the agency has created a designated public forum. This means that the agency cannot delete materials/comments posted in that forum, unless that restriction served a compelling state interest, and one which is narrowly tailored to achieve that interest (Tappendorf, 2013).

\subsection{Right to Privacy (Fourth Amendment)}

Government employees also have certain rights to privacy when there is a legitimate expectation of privacy which in turn also provides them some protection against unreasonable searches and seizures. How much privacy do employees have on information they post/share on social media? How much rights they have in sharing their concerns in social media about management? The increasing use of social media poses a great challenge since "employee's expectations of privacy can extend to computers, electronic devices, stored communication, etc. by virtue of allowing password protections and the like (Jacobson and Tufts, 2013, p. 7). In City of Ontario v. Quon (2010), the court ruled that public employees have no right to privacy regarding their use of department issued electronic devices, if their employers have a 'legitimate work-related" reason to search electronic files. In this case, Quon, a SWAT member received a pager for work related uses. The agency's policy stated that the agency reserved the right to monitor their employees' use of the device and that employees should not expect confidentiality. Quon exceeded his monthly text message amount several times and paid the city back for the excess. The City audited his text messages and found that many of the messages were used for personal reasons, and hence he was disciplined. The employees filed a claim in a federal district court against the police department on the allegations of violations of privacy rights. The district court ruled in favor of the defendants; the appeal court reversed the ruling. However, the Supreme Court ruled in favor of the City and explained that the City did not violate its employees' Fourth Amendment rights because the City's search of Quon's text messages was reasonable and motivated by a legitimate work-related purpose and was not excessive in scope. This case underscored the importance of crafting a well written social media policy.

\subsection{Open Meeting Laws/Acts}

Government agencies must abide by the Open Meeting Act. The Act requires that governmental decision making, and legislation are made openly, so the general public are fully informed and are given an opportunity to participate. It also requires public notifications of such meetings and record keeping of minutes. Examples of such meetings include the city council meetings, public hearings on proposed regulations, forums to increase awareness of an issue, and many other information sharing forums that affect the public or a segment of the 
public. “. . . conversation on the Internet among public officials can constitute an unlawful 'meeting' within the meaning of open meeting laws" (Institute for Local Government, 2010, p. 12). As Tappendorf (2013) also points out, that these "seemingly informal communication "(such as blogging, tweeting, messaging) can constitute a meeting under most open meeting laws". All these strongly suggests that government agencies cannot rely solely on social media to connect with the citizens or to inform them of upcoming meetings and public hearings. They have to find other ways, such as relying on traditional public media outlets like the newspaper, agency newsletter, and etc.

\subsection{Freedom of Information Act and Record Retention Laws}

Government agencies also must abide by the Freedom of Information Act (FOIA) which grants the public the right to have access to government agencies' records. Federal and State governments have record retention laws/statutes and provide schedules, which agencies are required to abide by. The issue is whether public agencies' postings on social media are public records for purposes of public records retention or records production requirements. Some states such as California have encountered this issue and have determined that these records are subject to FOIA. In City of San Jose v. Superior Court (2017), the California Supreme Court ruled that records in a local public agency employees' personal accounts or devices may be subject to the California Public Records Act (CPRA) if the records pertain to public business. In a previous case in 2009, The Florida Attorney General determined that a City Facebook page falls within Florida's definition of public record (Institute for Local Government, 2010, p. 15).

\subsection{Inadvertent Discrimination}

Government agencies also need to keep in mind that some individuals in the community are unable to access the internet for a variety of reasons. One such reason is the reality of the digital divide. For those individuals, who lack this access to social media, government agencies' extensive or sole reliance on social media could be perceived as an issue of discrimination. Thus, government agencies, unlike private agencies, are responsible to find alternative ways to provide information to this and other groups of individuals who for one or more reasons may not have access to social media or may not feel at ease (such as the elderly population) to use social media.

Another issue for employers, while surfing the net to gather information about prospective employees or job applicants, is discovering socio-demographic information (such as, age and gender) which are considered as illegal information to use for any employment decisions. A recent survey (CareerBuilder, 2018) found that $70 \%$ of employers use social networking sites to research job candidates, and $57 \%$ of these employers have used this information not to hire candidates. Since social media could provide a variety of socio-economic information about a prospective candidate, one needs to be careful and thoughtful that he or she is not inadvertently using that information to screen applicants. One also needs to be cognizant that all information found on the internet are not necessarily true. The fact is that anyone could post any fake information online. Even though these issues apply to all types of organizations, government employees should be extra careful about these since they are considered the 
vanguards of equity and fairness.

\section{Relevant Laws \& Policy Guidance}

\subsection{Federal laws}

There are no federal laws that directly address an individual's privacy rights as they relate to social media. The one related Federal Act, the Stored Communication ACT (SCA), only provides some parameters on this issue. The SCA basically prohibits the intentional accessing of electronic communications without any authorization. An interesting case related to this Act is the Pietrylo v. Hillstone (2009) case. The case involved two employees who had created and used a password protected Myspace page for employees to share and discuss among themselves their frustrations with the agency and the managers. One of the managers became award of this Myspace page and its contents. He obtained the password from one of the employees and fired the two employees who created that page. These two employees later sued the manager and alleged, among other things, that the manager had violated the SCA. The jury found that the employee felt pressured to give the manager the password, and hence concluded that the manager had accessed the site without authorization, which thereby was a violation of the SCA.

There are currently two bills, related to this issue, that have been introduced in the House of Congress. One is the Federal Password Protection Act and the other is the Social Networking Online Protection Act. Both laws include provisions that barred employers to compel or coerce employees to provide password to access the employees' personal social media accounts. However, neither bill has been acted upon or approved.

\subsection{Equal Employment Opportunity Commission (EEOC)}

The EEOC oversees the implementations of several anti-discrimination laws, such as the Civil Rights Act, Age Discrimination Act, sexual harassment, and the Americans with Disabilities Act. This agency is also increasingly dealing with social media related complaints. For example, in 2012, the agency deliberated on a case that involved social media and hostile work environment. The case involved an employee who filed a complaint against a co-worker on the ground that he was making racially disparaging comments about him on Facebook after he made an office "food run" to Chick-fil-A. As per the story, the alleged harasser was upset since this restaurant had an anti-gay reputation. The disparaging comments spread in social media, and the employee complained that other co-workers started to mock and harass him. The agency dismissed his complaints on the ground that there was no harassment. However, the EEOC after hearing the appeal reversed the agency's decision and stated that the employee did face a hostile work environment, and that the postings did create an unlawful hostile work environment.

In another complaint filed to the EEOC, a 61-year-old woman alleged age and sex discrimination after she was not selected for a Park Ranger position. She alleged that since the agency recruited applicants through Facebook for that position, it disadvantaged older workers who use the internet less frequently. The EEO however found no evidence of this discrimination (Moore, 2014). 
Very recently, in 2018, three women filed a complaint with the EEOC against Facebook and nine employers. The allegation was that Facebook ad filtering kept them from seeing job postings in male-dominated fields, such as construction (Guynn, 2018).

\subsection{U.S. Office of Government Ethics and the Office of Special Counsel}

The United States Office of Government Ethics, in 2015, developed some guidance on Standards of Conduct as Applied to Personal Social Media use by federal employees.

As per the guidance, a violation might occur if an employee "refers to his or her connections to the government as support for the employee's statements". A violation could also occur if an employee "prominently features his or her agency's name, seal, uniform or similar items on the employee's social media account or in connection with specific social media activities", among other situations.

The Office of Special Counsel, which enforces the Hatch Act - also provides some guidance. One part of the guidance states that there is no violation of the Act on soliciting donations for parties or partisan candidates if a social media "friend" of a federal employee posts a link to the contribution page of a partisan candidate on the employee's page. However, the employee should not "like" "share", or "retweet" the solicitation, or "respond in any way that would tend to encourage other readers to donate" (Yoder, 2015).

\subsection{National Labor Relations Board (NLRB)}

The NLRB is responsible for enforcing the National Labor Relations Act (NLRA). Section 7 of the Act grants certain rights to employees, including the right to engage in "concerted activities for the purpose of . . mutual aid or protection". This includes the right to publicly discuss terms and conditions of their employment. Section 8 of the NLRA prohibits employers from interfering with, restraining, or coercing employees in the exercise of their section 7 rights. The NLRB has deliberated and adjudicated several cases involving employees use of social media. Even though the NLRB does not apply to government organizations, these rulings, nonetheless, do provide some guidance to public sector employees and employers. In several of these cases the NLRB's rulings provided insights on developing valid social media policy.

In Durham School Services, L.P. v. NLRB (2014), an employer who operated a fleet of school buses had a social media policy. One part of the policy included a disciplinary provision for "employees who publicly share unfavorable written, audio or video information related to the company or any of its employees or customers". The NLRB ruled that the policy was unreasonably broad and vague and that employees could interpret the policy as infringing on their rights to communicate with each other regarding work issues (Murphy, 2015).

In Lily Transportation v. NLRB (2014), the transportation agency's policy on maintaining confidentiality states that any disclosure of confidential information could result in termination. Here too, the NLRB ruled that this policy was too broad and that employees could interpret the policy as prohibiting them from discussing wages and other terms and 
conditions of employment.

\subsection{State Level Developments}

States are, in fact, ahead of the federal government when it comes to protecting employee rights as they relate to social media use. As per the National Conference of State Legislatures website

(http://www.ncsl.org/research/telecommunications-and-information-technology/state-laws-pr ohibiting-access-to-social-media-usernames-and-passwords.aspx), 26 states have enacted laws that bar employers from requiring their employees to share with them their social media accounts' passwords. Some state laws have some reasonable exceptions. One example is Maryland. Its law include two such exceptions: (1) allows an employer upon learning that an employee has used his or her personal account for business purposes to conduct an investigation to ensure compliance with applicable financial or security laws or regulatory requirements, and (2) allows them to conduct an investigation upon learning that the employee has downloaded the employer's proprietary or financial data without proper authorization (Stiegler, 2015-16).

\section{A Case Study: Findings From the Student Quiz}

Students at this Midwestern State University's MPA program are overwhelmingly nontraditional, with approximately $90 \%$ in-career students. Most of these in-career students work in a variety of public sector organizations. A short quiz was distributed during a three semester periods to students enrolled in the online graduate Human Resource Management course. Students in this online course were required to participate in this short quiz during the first week of the semester to remain enrolled in the course. As per the University policy, students who do not complete a quiz or other requirements set forth by the course instructor, during the first week of the semester, may be dropped from the course for non-participation. This policy applies to all courses, online and face to face.

The instructor had informed the students that the quiz would not be graded, and that they had 10 minutes to complete this assignment. This brief quiz was an exploratory one and focused on understanding these students' knowledge and awareness of some of the legal developments and issues related to social media usage discussed in this paper. The quiz had the following questions, with "Yes", "No", and "Not Sure" answers to choose from:

1. Is 'liking' someone's Facebook page a speech that is protected by the First Amendment Rights?

2. Could a government agency, at its discretion, delete materials or comments posted by citizens on its social media sites?

3. Does your agency have a social media policy?

4. If your agency has a social media policy, have you read it?

5. If a city council decides to conduct its council's meetings online, will that raise any legal issues? 
6. Could your employer ask for your social media accounts passwords?

7. Do you see any legal issues in using social media outlets to research job applicants and using those information to make hiring decisions?

As mentioned, this quiz was an exploratory one, and did not include any demographic questions, nor did it provided any scope for students to write any comments. In addition to using this quiz to complete the attendance report, the instructor also wanted this as a base to develop a full-fledged survey, in the near future, on city administrators' understanding of these issues.

The total number of students who completed this online quiz was 51. The following Table reports the findings.

Table 1. Quiz Findings

\begin{tabular}{|c|c|c|c|c|}
\hline & Questions & Yes & No & Not Sure \\
\hline 1 & $\begin{array}{l}\text { Is 'liking' someone's Facebook } \\
\text { page a speech protected by the Frist } \\
\text { Amendment? }\end{array}$ & 3 & & 48 \\
\hline 2 & $\begin{array}{l}\text { Could a government agency, at its } \\
\text { discretion, delete materials or } \\
\text { comments posted by citizens on its } \\
\text { social network? }\end{array}$ & 10 & 18 & 23 \\
\hline $3 a$ & $\begin{array}{l}\text { Does your agency have a social } \\
\text { media policy? }\end{array}$ & 16 & & 35 \\
\hline $3 b$ & $\begin{array}{l}\text { If you agency has a social media } \\
\text { policy, have you read it? }\end{array}$ & 5 & 11 & \\
\hline 4 & $\begin{array}{l}\text { If a city council decides to conduct } \\
\text { its council's meetings online, will } \\
\text { that raise any legal issues? }\end{array}$ & 30 & & 21 \\
\hline 5 & $\begin{array}{l}\text { Could you employer ask for your } \\
\text { passwords for your social media } \\
\text { accounts? }\end{array}$ & 1 & 17 & 33 \\
\hline 6 & $\begin{array}{l}\text { Do you see any legal issues in using } \\
\text { information from social media } \\
\text { outlets in making hiring decisions? }\end{array}$ & 9 & 20 & 22 \\
\hline
\end{tabular}

As Table I reports, $60 \%$ of the students are unsure whether 'liking' someone's Facebook page is a speech that is protected by the First Amendment Rights. A predominant majority $(76.5 \%)$ of the students are also unsure whether a governmental agency could delete materials and comments posted by citizens on its social media sites. Another $45.1 \%$ of these student respondents are unsure whether their agencies have a social media policy. Among those who do have a social media policy, $72.7 \%$ reported that they have not read that policy. Interestingly, $68.6 \%$ of the students think that their employers could not ask for their social 
media accounts' passwords - this finding is somewhat interesting since the three states where these students reside don't have the password protection laws. Overall, the findings from this short quiz indicate that most of these in-career students are not aware of the recent legal developments and the legal issues surrounding social media use in the workplace. The only exception is the finding that a significant majority (78.4) of this student respondents report that a city council's online meetings will raise legal issues. The findings are somewhat disconcerting, since most of these students are working in a variety of government organizations, and at managerial positions.

\section{In Conclusion: Use of Pro-Active Strategies and Ongoing Learning}

Social media use in the workplace with all its benefits and challenges is not only going to remain active but will lead to many new creative and beneficial uses. The challenge is for both the employers and employees to use it in a productive way while at the same time to avoid the pitfalls of its many usages. For the public sector, as the paper discusses, some of the issues are related to a variety of constitutional and legal matters. Currently the legal landscape has only started to develop. This paper discusses many of these legal issues and court cases/rulings that offer some guidance to public sector employers and employees about their rights and restrictions in using social media in the workplace. The discussion also points out some gray areas. Even though one cannot generalize the findings from the short quiz, the findings do indicate that the student respondents who work in a variety of public sector organizations lack crucial knowledge on current legal issues related to use of social media in the workplace.

One of the main issues here is balancing employers' rights for workplace efficiency and effectiveness versus employees' rights for freedom of expression and privacy. As Klingner and Nalbandian (2003) explained, public sector employees "have more privacy rights than their private sector counterparts. The constitution, as well as the state statutes and federal laws like the Freedom of Information Act and the Electronic Communications Privacy act, protect these rights" (p. 333). In such an employment relationship, it is crucial that the employer clearly communicate to employees its expectations on employees versus employers rights. One of the effective ways to do so is to have a clear and specific social media usage policy.

Cohen (2013) argued that such policy should cover at the minimum the following items:

1. Introduction, which will set the context and background of the policy so employees will understand the issues.

2. A statement of rationale for the policy.

3. Scope of use of social media (such as total ban, limited use, etc.).

4. Compliance expectation and consequence of policy violation.

5. Intellectual property protection. 
6. Authorization requirements and process for content pre-approval and specifying the level of approval process.

7. General requirements and guidelines on exercise of good judgment and professionalism.

8. Explicit disclaimer to make it clear that employees' postings do not represent the official viewpoint of the agency.

9. Emphasize that social media has no privacy.

10. Examples of topics that can or cannot be discussed on social media postings.

11. Confidentiality statement.

12. Legal liability to clarify employees' possible legal liabilities in their use of social media.

13. Prohibit photos and videos which are unprofessional and compromising.

14. An acknowledgement form/page documenting receipt of the policy.

The policy should also include a process to report violations of this policy and consequences of such violations.

Another important strategy is to provide training to employees to not only explain the policy but also to discuss how to use it productively and not face any legal issues. Such training should be a priority in all organizations. As mentioned above, Table I reports that a significant majority of the student respondents have not read their agencies' social media policy. Considering the reality that both employees and employers in the public sector use social media in the workplace, albeit for different reasons, it is important for both parties to be fully aware of the relevant legal precedence and developments. For employers, it is crucial that they understand their rights versus employees' rights regarding social media use in the workplace. The same applies to employees - they also need to have a clear understanding of their rights versus employers' rights in the use of social media. Since one of the main responsibilities of an agency's human resource department is to develop and offer training to all employees, it could form partnership with the legal department or the legal counsel and offer training on legal developments and issues in workplace social media use. The training program could use real cases and also hypothetical scenarios on social media issues to make learning more impactful for the trainees. It will also be beneficial to include a section on social media policy and relevant legal issues during the new employee orientation program.

Even though this paper focuses on the legal issues related to the use of social media in the workplace, one also needs to keep in mind the broader picture when it comes to social media's contributions to the workplace. Among its many contributions, use of social media in the workplace have been found to led to job satisfaction (Demircioglu, 2018), innovations in the public sector (Mergel, 2016), and increase in organizational citizenship behaviors (Hsu \& Lin, 2008). Social media offers an effective channel for employees to raise and share their voice. Use of social media in the workplace is considered as a new form of employee voice (Holland et al., 2016). All these heighten the importance for employers and employees to appreciate the values of appropriate uses of social media in the workplace and the importance 
to maintain a balance between employers' rights versus employees' rights.

The short case study which reported the findings from the quiz that students completed had its limitations in terms of the methodology. As mentioned before, the author wanted this as a base to develop a comprehensive survey on public sector employees' understanding and knowledge on these legal developments. The goals of the survey will be to identify areas of training and knowledge development on workplace use of social media, both for practitioners and also for classroom teaching. The latter is crucial for students in MPA programs, since the MPA program is the training ground for most of our public sector managers and future leaders. Public sector employees also have to be cognizant of the possibility of engaging in inadvertent discrimination when they browse social media to find information on current or prospective employees and become aware of demographic information which are illegal to use for any employment related decisions. Public sector employees also should use due diligence while using social media in the workplace, since we all expect a higher sense of ethics, morality and good citizenship behaviors from them.

\section{References}

CareerBuilder (2018). Press Releases. More than Half of Employers Have Found Content on Social Media That Caused Them Not to Hire a Candidate, According to Recent CareerBuilder Survey. [Online] Available: http://press.careerbuilder.com/2018-08-09-More-Than-Half-of-Employers-Have-Found-Cont ent-on-Social-Media-That-Caused-Them-NOT-to-Hire-a-Candidate-According-to-Recent-Ca reerBuilder-Survey (February 1, 2019).

Carpenter, C. A. (2009). The Machine: Techno-politics 2.0. In Conference proceedings: YouTube and the 2008 election cycle (pp. 189-190)/ Amherst, MA: ScholarWorks@uMassAmherst.

Cohen, A. (2013). Social Media, Legal Risk and Corporate Policy. NY: Wolters Kluwer \& Business.

Demircioglu, M. A. (2018). Examining the Effects of Social Media Use on Job Satisfaction in the Australian Public Service: Testing Self-Determination Theory. Public Performance Management Review, 41(2), 300-327. https://doi.org/10.1080/15309576.2017.1400991

Guynn, J. (2018). Facebook accused of bias in job ads that let companies target men exclude women.

[Online]

Available:https://www.usatoday.com/story/tech/news/2018/09/18/facebook-men-only-ads-dis criminate-against-women-other-genders-eeoc-complaint/1341473002/ (January 18, 2019).

Holland, P., Cooper, B. K., \& Hecker, R. (2016). Use of Social Media at work: a new form of employee voice? The International Journal of Human Resource Management, 27(21), 2621-2634. https://doi.org/10.1080/09585192.2016.1227867

Hsu, C. L., \& Lin, J. C. (2008). Acceptance of Blog Usage: The roles of technology acceptance, social influence, and knowledge sharing motivation. Information \& Management, 45(1), 65-74. https://doi.org/10.1016/j.im.2007.11.001 


\section{Ml Macrothink}

Journal of Public Administration and Governance

ISSN 2161-7104

2020, Vol. 10, No. 1

Institute for local Government (2010). Social Media and Public Agencies: Legal Issues to Be Aware of. [Online] Available: http://www.ca-ilg.org/sites/main/files/file-attachments/resources_Technology_Legal_Issues _Clean_1_10.pdf. (July 1, 2019).

Jacobson, W. S., \& Tufts, S. H. (2013). To Post or Not to Post: Employee Rights and Social Media. Review of Public Personnel Administration, 33(1), 84-107. https://doi.org/10.1177/0734371X12443265

Klingner, D. E., \& Nalbandian, J. (2003). Public Personnel Management. Contexts and Strategies. NJ: Prentice Hall.

Mergel, I. (2013). Social Media in the Public Sector. A Guide to Participation, Collaboration, and Transparency in the Networked World. CA: Jossey Bass.

Mergel, J. (2016). Social Media Institutionalization in the U.S. Federal Government. Government Information Quarterly, 33(1), 142-148. https://doi.org/10.1016/j.giq.2015.09.002

Moore, J. (2014). Think before you post: EEOC cases show pitfalls of social media in the workplace.

Available: https://federalnewsnetwork.com/technology-main/2014/03/think-before-you-post-eeoc-casesshow-pitfalls-of-social-media-in-the-workplace/ (January 18, 2019).

Murphy, D. (2015). The Social Media World According to the NLRB: Part I of the Social Media Series. [Online] Available: https://www.constangy.com/newsroom-newsletters-572 (January 30, 2019).

Nolo (2011). Monitoring employees' off-duty conduct.: Should you keep track of what employees do when they're not on the job? [Online] Available: https://www.nolo.com/legal-encyclopedia/monitoring-employees-off-duty-conduct-29994.ht ml. (October 20, 2018).

Russell, J. (2017). Social Media in Government: Benefits, Challenges, and How it's Used. [Online] Available: http://www.marketinghub.today/social-media-in-government-benefits-challenges-and-how-its -used/. (October 10, 2018).

Stiegler, C. J. (2015-16). Developments in Employment Law and Social Media. The Business Lawyer, 71(1), 321-332.

Tappendorf, J. A. (2013). Social Media \& Governments - Legal \& Ethical Issues. [Online] Aavailable: https://www.in.gov/ig/files/Julie_Tappendorf.pdf. (July 23, 2019).

Yoder, E. (2015). Think before you post: Here's the new federal workforce guidance on social media. [Online] Available: https://www.washingtonpost.com/news/federal-eye/wp/2015/04/16/think-before-you-post-her es-the-new-federal-workforce-guidance-on-social-media/?utm_term=.b14595bb9a76. (January 20, 2019). 


\section{Copyright Disclaimer}

Copyright for this article is retained by the author(s), with first publication rights granted to the journal.

This is an open-access article distributed under the terms and conditions of the Creative Commons Attribution license (http://creativecommons.org/licenses/by/4.0/). 